\title{
RNA, Hydrothermal Systems, Zeolites and the Origin of Life
}

\author{
by Euan G. Nisbet
}

Recent discoveries in molecular biology suggest that life began with RNA, perhaps more than $4 \times 10^{9}$ years ago. The first RNA molecules may have formed in hydrothermal systems where $\mathrm{CH}_{4}, \mathrm{NH}_{3}$, and phosphate were freely available. Zeolites with their protective cage structure could have acted as the necessary catalysts for the construction of RNA molecules in pores and vesicles in lavas. This early RNA world may have developed by the binding of proteins and then by the invention of an enclosing membrane. Variations in hydrothermal activity or earthquakes could have released the new living organisms into the ocean where they could colonize the sea floor. This article develops the RNA model and assesses other explanations for the origin of life in the light of their biological and geological plausibility.

\section{The Components of Life}

The origin of life is the most challenging and perhaps the most intractable of all geological problems. Although we cannot define life, we can describe its properties. In essence, life is sustained thermodynamic disequilibrium, which in time creates an ever-growing degree of local order. This is done by self-replication, even though not all living things can replicate. Von Neumann (1966) showed that any self-replicating machine must have both a list of instructions and a set of organs that help the list to reproduce.

In living organisms, the list of instructions is made from RNA (ribonucleic acid) and DNA (deoxyribonucleic acid), which are in turn made from sugars, bases and phosphates. The sugar is ribose $\left(\mathrm{C}_{5} \mathrm{H}_{10} \mathrm{O}_{5}\right)$ in $\mathrm{RNA}$ and deoxyribose $\left(\mathrm{C}_{5} \mathrm{H}_{10} \mathrm{O}_{4}\right)$ in DNA. The bases are nitrogen-containing ring compounds, either purines or pyrimidines: adenine, guanine, cytosine and thymine in DNA and adenine, guanine, cytosine and uracil in RNA. The combination of sugar, base and phosphate is known as a nucleotide and the acids are polynucleotides.

Figure lA shows the general structure of RNA - a sugarphosphate chain with nitrogen bases branching off the sugar. Figure 1B shows in more detail the sugar, which is ribose, and the four bases. Information is stored as the order of succession of the bases along the molecule.

The cellular "organs," which help in replication, are mostly proteins, themselves chains of amino acids. There are 20 common amino acids necessary to life, each containing a carboxylic group, $\mathrm{COOH}$, and an amino group, $\mathrm{NH}_{2}$, (Fig. 2A). In forming a protein, amino acids are linked by polycondensation, which eliminates water and produces peptide bonds ( $\mathrm{CO}-\mathrm{NH}-$ ), as shown in Figure 2B. The peptides link together a chain of amino acids to form a polypeptide or protein, the workhorse of the cell. Some act as catalysts (enzymes) that help in the replication of nucleic acids and in the construction of the cell. These organs have a bag or membrane around them, made of phospholipids (small water-insoluble molecules built of fatty acids, glycerol and phosphate) with proteins embedded in them. This membrane protects the local order within the cell from the surrounding environment. Both the list of instructions and the organs are thus confined within the bag and do not drift away.

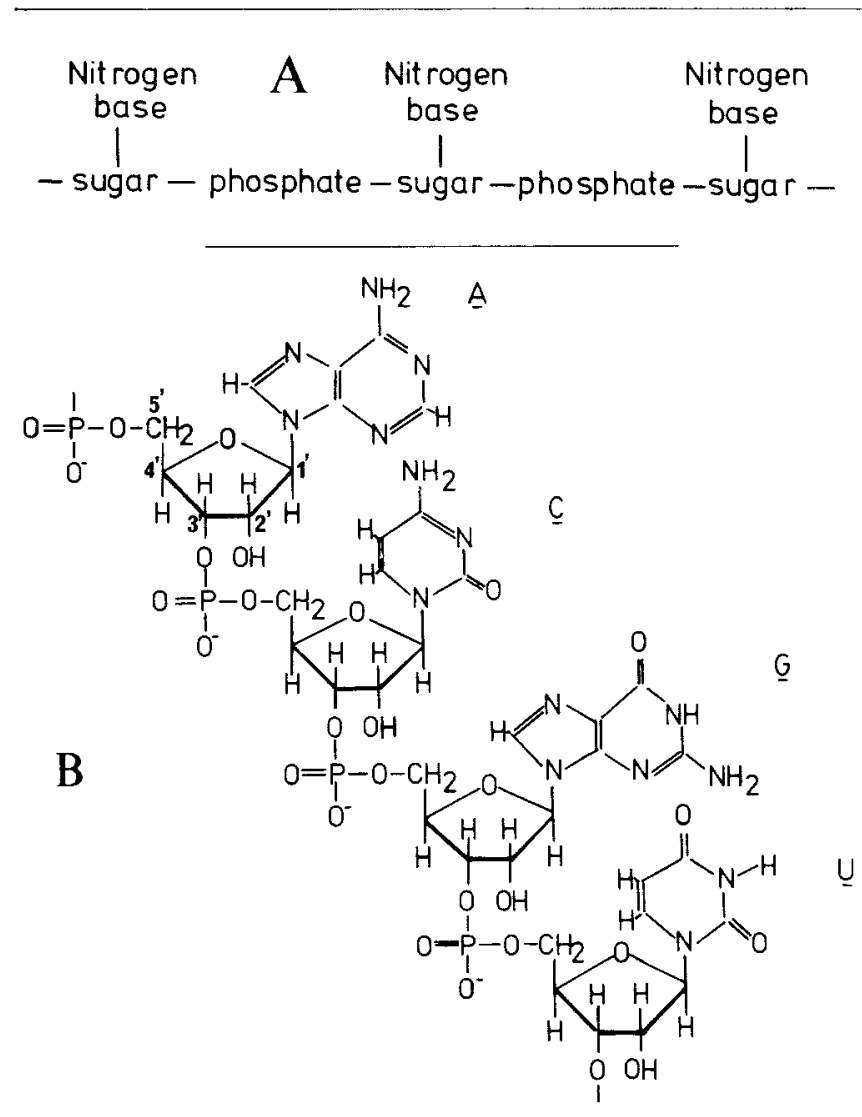

Figure 1: The structure of RNA. In $B$, the position of the $C$ atoms is shown by $I^{\prime}, 2^{\prime}, . .$. . A - adenine, $C$ - cytosine, $G$ - guanine, $\underline{U}$ - uracil. 


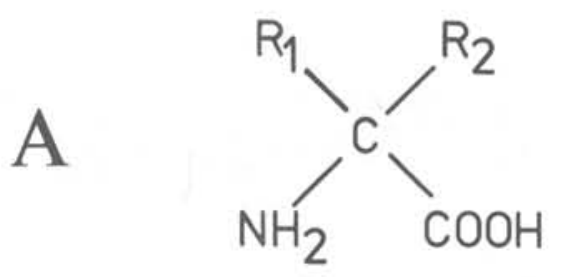

B

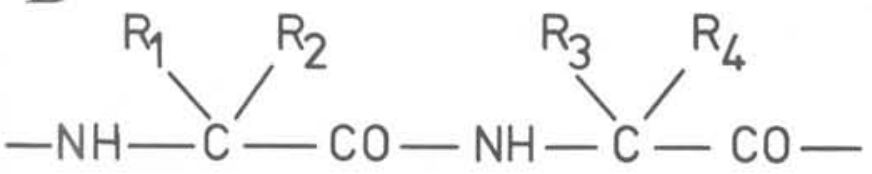

Figure 2: Amino acids (A) and proteins (B). In life $R_{2}$ and $R_{4}$ are $H$ atoms.

In modern cells, proteins are formed according to the code of instructions contained in the base sequence of DNA, which is transferred into an RNA sequence. The latter then directs the construction of a specific amino acid sequence to make a protein. Some of these proteins act as enzymes, or catalysts of very specific shape, to offer surfaces on which the nucleic acid "list" can itself be duplicated. Thus, in order to make a protein, a code of instructions from a nucleic acid is needed, but to replicate that code the aid of an enzyme is required. The whole system consisting of DNA, RNA, enzymes to help replicate the list, and assorted organs including a containing bag is thus very complex. How on earth did it begin?

Most theories of the origin of life have concentrated on one aspect of the system and assume that the first life was much simpler than a modern cell. Some models regard both nucleic acids and the container as later additions, assuming that life began with self-replicating proteins. Other approaches assume that acids and protein post-date the container; yet others appeal to the unlikely event that the two components were assembled together by accident or by some crystalline precursor. However, RNA-based models have recently received much support and provide perhaps the only really coherent explanation of how life began.

\section{The Geological Setting: When and Where?}

Life began at least $3.6 \mathrm{Ga}$ ago and probably prior to $4.0 \mathrm{Ga}$. Stromatolites in rocks $3.5-3.6$ Ga old from Barberton, South Africa (Byerly et al., 1986), and from the Pilbara, Western Australia (Buick et al., 1981), provide the oldest macroscopic record of life. Carbon isotopes in rocks from Isua, Greenland, suggest that the modern carbon cycle was established by $3.8 \mathrm{Ga}$ ago (Schidlowski, 1980). If stromatolites (Figs. 3, 4) were built by cyanobacteria (bluegreen algae), and if the carbon cycle reflects the operation of the major biochemical reaction pathways, we can make some guesses about when life began.

The line of descent of early organisms has been established by the study of RNA and proteins. It seems probable from recent work on amino acid sequences of proteins and especially on RNA sequences in relatively short ribosomal molecules that the three major divisions of life, archaebacteria (which today often live in extreme environments such as hydrothermal systems, hot springs, and human sewage systems), eubacteria (most modern bacteria) and eucaryotes (cells with nuclei) were present early in the geological record, and that a considerable time elapsed before cyanobacteria evolved. By implication, life began well before Isua time and probably well prior to $4 \mathrm{Ga}$ ago.
As to the nature of the geological environment in the early Archaean, thermal considerations strongly suggest that if plate tectonics did not operate then, there must have been some similar process in existence in order to manage the Earth's heat budget (Bickle, 1978). Most probably the Archaean tectonic scheme was broadly similar to that of today, but rather more active and involving more heat dissipation at the ridges. This would imply faster spreading at ridges, a longer ridge system, or the presence there of hotter (komatiitic) liquids or, most likely, a combination of all three factors.

Opinion is divided as to whether large continents existed in the earliest Archaean, but the record from Australia of 4.2 Ga-old zircons (Froude et al., 1983) suggests that at least some silicic land masses were present. This conclusion is supported by the discovery of $3-3.5$ Ga old diamonds (Richardson et al., 1984): to produce them, cool continental lithosphere must have existed, implying the differentiation of at least some large continental masses well prior to 3.5 Ga ago.

There is much controversy about the nature and composition of the oceans and atmosphere. Evidence from rare gases (Ozima et al., 1985) clearly demonstrates that there was substantial degassing of the atmosphere prior to $4.4 \mathrm{Ga}$ ago. The preserved thickness of Archaean continental masses implies that oceans were at least as deep as today and probably covered the mid-ocean ridges (Nisbet, 1984). Thus both atmosphere and ocean existed then.

The composition and temperature of the modern atmosphere is essentially controlled by "Gaian" biological feedback loops (Lovelock, 1979). As a crude example of this, if volcanics were to de-gas vastly abnormal volumes of $\mathrm{CO}_{2}$, the global temperature would rise via the greenhouse effect. Under such conditions, life would flourish and, over a geologically short period, would precipitate carbon and carbonate. This would rapidly restore global conditions to normal levels. Since the major biochemical pathways were established in the early Archaean, it is reasonable to suppose that these controls existed then too: cyanobacteria and chloroplasts, which carry out photosynthesis in plants, are closely related, for instance.

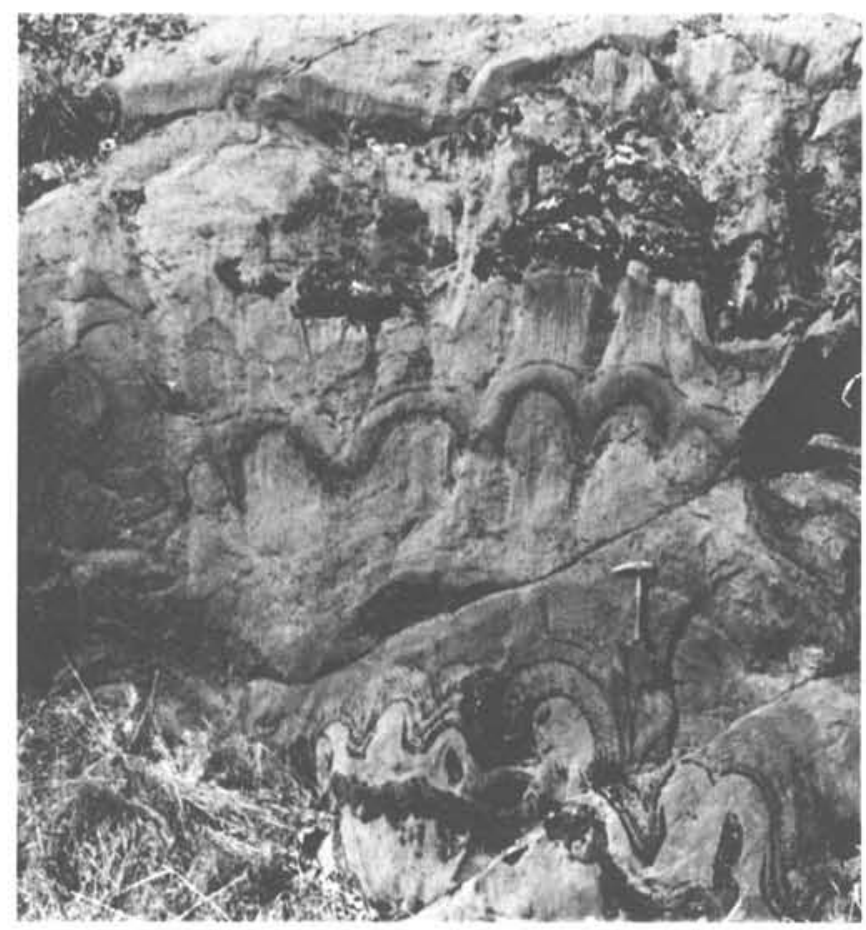

Figure 3: Stromatolites of the Cheshire Formation, Belingwe greenstone belt, zimbabwe $(2.7 \mathrm{Ga})$. 
Many geochemical models (Holland, 1984) suggest that free oxygen was not present in the Archaean atmosphere, but the geological evidence on which this is based can be challenged. For instance, sulphates are widespread in the early Archaean record. Possible bauxite has been reported from strata around $3 \mathrm{Ga}$ old in Ontario (Jolliffe, 1955), and redbeds are known from the Proterozoic of Saskatchewan (Langford, 1981). Furthermore, mineral assemblages in palaeosols, which have been interpreted to imply reducing conditions during formation, may have been metamorphosed.

Towe (1983) suggested that in the earliest Archaean a moist greenhouse may have developed. In such a setting water would have mixed into the upper atmosphere, and the oceans would have lost much hydrogen to space, leaving a residual oxidized Earth and a deuterium-rich ocean. Something of this sort appears to have taken place on Venus, which lost its Archaean oceans in a dehydrating greenhouse (Watson et al., 1984). While there is thus no agreement about its oxidation state, there is a consensus that methane $\left(\mathrm{CH}_{4}\right)$ and ammonia $\left(\mathrm{NH}_{3}\right)$ could not have been significant species in the Archaean atmosphere (Abelson, 1966, Henderson-Sellers and Cogley, 1982, Nisbet and Pillinger, 1981). Models that appeal to the formation of amino acid by lightning strikes in an ammonia-methane atmosphere are not likely.

As to the composition of the ocean, there is a similar disagreement. Many biologists refer to the mysterious emergence of life from a primeval "soup," but this is geologically most improbable. On the modern Earth, a volume of seawater equal to the total volume of the oceans is processed through the mid-ocean ridge hydrothermal systems every $10^{7}$ years (van Andel, 1983). In the early Archaean this rate would have been much greater - perhaps once every $10^{6}$ years - in order to dissipate the ridge heat. Then, as today, cycling seawater through oceanic crust would have been the dominant control on seawater chemistry. The oceans were probably neutral to mildly alkaline (Abelson, 1966), and any organic soup would soon be cracked by passage at several hundred degrees through the hydrothermal systems. If the seas were neutral, a very $\mathrm{CO}_{2}$-rich atmosphere could not have existed for long: precipitation of carbonate in the ridge hydrothermal systems would have removed much $\mathrm{C}$ from the exosphere in around $10^{8}$ years.

Such a situation may have been rather fortunate, for with a $\mathrm{CO}_{2}$ atmosphere there would have been a massive greenhouse contribution to the surface temperature, and the atmospheric cold trap would probably have broken down, allowing mixing of $\mathrm{H}_{2} \mathrm{O}$ into the upper atmosphere (Kasting et al., 1984). This would have led to Towe's moist greenhouse (1983), with massive loss of $\mathrm{H}$ via solar ultraviolet radiation, and planetary dehydration. Perhaps such a greenhouse loss of water did occur, but since we still have oceans, the implications are that very high partial pressures of $\mathrm{CO}_{2}$ did not persist in the atmosphere for more than a few hundred million years. Moreover, it appears that the surface temperature has been maintained in the range $0-40^{\circ} \mathrm{C}$ ever since, for had it risen above $40-50^{\circ} \mathrm{C}$ dehydration would have taken place (Kasting et al., 1984).

Here the "faint young sun" paradox arises. The young sun was much weaker than today, and solar luminosity has steadily increased over geological time. To maintain a fluid ocean, the atmosphere greenhouse effect must have been substantially greater than today. As the sun warmed up over time, the Gaian biological control may have reduced the greenhouse by lowering the $\mathrm{CO}_{2}$ content of the air to maintain a steady surface temperature.

To summarize, four billion years ago the Earth had a surface temperature in the range $0-40^{\circ} \mathrm{C}$, deep oceans, and an atmosphere, which may or may not have been oxidizing but certainly contained negligible $\mathrm{CH}_{4}$ and $\mathrm{NH}_{3}$. The oceans were probably neutral to mildly alkaline and were not a

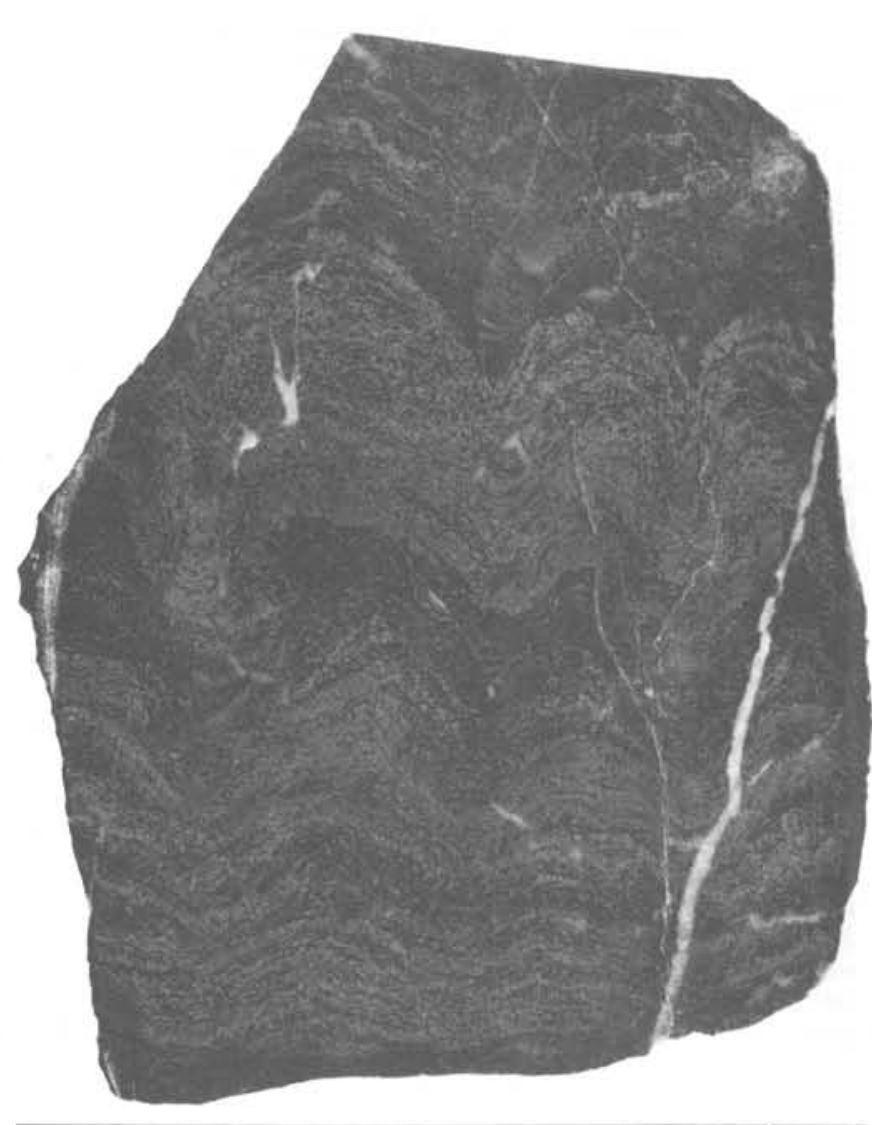

Figure 4: Close-up of etched surface of Cheshire stromatolites. $9 \mathrm{~cm}$ across.

thick soup of organic chemicals. There may or may not have been continents with dry land, and plate tectonies or something similar probably operated.

\section{Models of the First Life}

Somehow life began. Some hypotheses invoke the seeding of life from outer space. Hoyle and Wickramasinghe (1978) suggested that life may have begun by the assembly of organic chemicals in bodies such as comets. More recently, Chappell et al. (1974) and Crick (1981) revived an old hypothesis dating back to Anaxagoras and, more recently, to Arrhenius, to suggest that the Earth was seeded deliberately from space by life forms that originated somewhere else.

The most popular and quoted models are those derived from the work of Oparin (1957) and Haldane (1928), who proposed that life began in some way in a "primeval soup." Later, Miller (1953) showed that complex organic chemicals could be synthesized in an atmosphere of $\mathrm{CH}_{4}, \mathrm{NH}_{3}$ and so forth. This hypothesis has proved to be very tenacious in the literature, despite its destruction by Abelson (1966).

More recent hypotheses avoid the need for soup. Fox and Dose (1977) suggested that the first life was proteinoidal, and that these proteins were put together in a special local environment, such as near a volcano. Woese $(1979,1980)$ suggested that life began in aerosols in the atmosphere, and Schwartz and Henderson-Sellers (1983) that it began near a voleano under a glacier. And there is always Darwin's 1877 (in de Beer, 1959) concept of a "warm little pond."

Cairns-Smith $(1982,1985)$ has developed what is one of the most interesting of all hypotheses. He suggests that life was originally based on the erystallization of clay minerals, an idea proposed earlier by Bernal (1951). In this model, life evolved through the influence of natural selection on the 
growth of inorganic crystals. The first genes were clay structures, with replication taking place by the breaking of $f$ of layers in the clay lattice. Later, organic chemicals were incorporated into the structure of the replicating crystallites, and eventually, through natural selection, the organic component became dominant. Nucleic acids were invented, taking over as the basic information record making up the genes of the organism.

To recapitulate, a self-replicating system consists of three components. These are a "list" of instructions (in life, RNA and DNA), a set of organs to help with replication (proteins), and finally a container organ to allow a local environment to be maintained so that list and replicating organs can go about their business. Models that invoke a soup do away with the container by postulating that the whole environment (the soup) supplies chemical components and help in replication. Other hypotheses, such as those involving proteinoid, effectively do away with the list. Yet others, such as the clay-mineral model, are in essence all "list." It seems almost impossible that all three components came together by chance on Earth: the only concepts that start with all three are those that have the Earth seeded from space. Many models invoke the remote chance that somehow two components could be assembled, and a few rely only on one. In the latter, natural selection is called upon to provide the missing components as life evolves.

\section{The RNA World}

The central dogma of biology is that information proceeds from DNA to RNA to protein and not from protein to

$$
\mathrm{DNA} \longrightarrow \mathrm{RNA} \longrightarrow \text { protein }
$$

nucleic acid. Intuitively, one can simplify matters by dispensing with DNA, since it probably came later as a more reliable information store than RNA. However, it is difficult to see how life could have started with protein because that would, at some time, require that RNA was assembled from a list of instructions encoded in protein.

A satisfactory protein-based hypothesis must, therefore, explain how protein could have been made by geological processes, how it could replicate itself, and how it could encode RNA. For clay-based models it is difficult to see how a daughter unit was reliably split off. Alternatively, if the model is RNA based, it must explain how RNA could have been made by geological processes and how it could reproduce.

Recent discoveries of some extraordinary properties of RNA have given much support to RNA-based models. The new concept is based on the discovery by Guerrier-Takada and Altman (1984) and Zaug and Cech (1986), as discussed below, that RNA can in certain circumstances detach a part of itself, which can then act as an enzyme, or "ribozyme," catalyst. It is thus possible that an "RNA world" existed in which molecules of RNA replicated themselves without the aid of proteins, given the right conditions (Gilbert, 1986). In a sense, RNA may be an even more elegant substance than DNA since it has the property of not only being a "list" controlling replication, but also can detach an "organ" that can help in the replication and that is itself a daughter of the original substance.
Figure 5: Conditions around a meteoric water/seawater hydrothermal system, close to a coast (after Kristmannsdottir, 1983). Solid arrow shows seawater movement, open arrow shows transport of meteoric water. Top layer - hyaloclastite, breccia and fragmental lavas; middle layer - lava flows; bottom layer - intrusive dikes, sills, etc. Inset shows typical time scale of $p H$ fluctuation (after Stefansson, 1983).

\section{The Geological Construction of the RNA World}

Could the RNA world have existed in reality? What are the geological requirements, and how could it have been put together? The essential requirements are

- a supply of organic chemicals,

- a mechanism and the correct chemical conditions for putting them together to make a molecule of RNA,

- some sort of container which will trap any detached length of RNA acting as a ribozyme so that it can help in assembling more RNA,

- a mechanism to allow escape of RNA to other locations it can colonize to build a population on which natural selection can act, and

- a mechanism to explain the development of "organs" such as proteins and,

- a membrane enclosing the whole proto-cell.

The Supply of Organic Chemicals

The only setting in which basic components such as $\mathrm{CH}_{4}$ and $\mathrm{NH}_{3}$ would have been freely available in the Archaean is in hydrothermal systems (Corliss et al., 1981). In some modern hydrothermal systems, such as on Iceland (Arnórsson, 1985), reactions such as

$$
\begin{aligned}
& \mathrm{CH}_{4}+2 \mathrm{H}_{2} \mathrm{O}=\mathrm{CO}_{2}+8 \mathrm{H}^{+}+8 \mathrm{e}^{-}, \text {and } \\
& 2 \mathrm{NH}_{3}=\mathrm{N}_{2}+6 \mathrm{H}^{+}+6 \mathrm{e}^{-}
\end{aligned}
$$

allow significant and variable concentrations of methane and ammonia to move through the rock matrix. $\mathrm{CO}$ is also present. In some cases, the partial pressure of $\mathrm{CH}_{4}$ in 


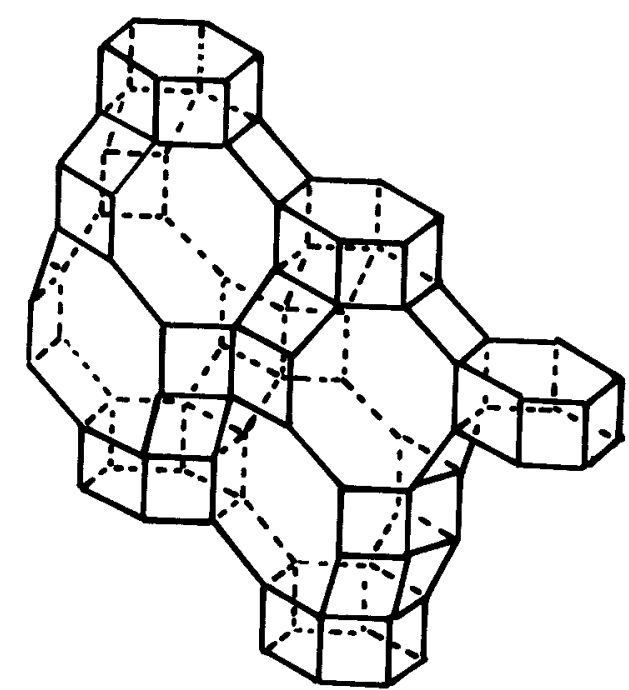

Figure 6: The chabazite framework, each unit of which contains a large cavity connected to those above and below by channels $3.9 \AA$ in diameter that allow the mineral to act as a molecular sieve.

geothermal water ranges up to one bar or more, showing no clear dependence on aquifer temperature: dilute geothermal waters and waters below $200^{\circ} \mathrm{C}$ depart considerably from equilibrium.

Probably only in and around the low-temperature regions of such hydrothermal systems could nucleotides have been synthesized inorganically in the early Earth. Many experiments (summarized by Fox and Dose, 1977) have shown how sugars can be produced, via formaldehyde made in the gas-water systems. This is especially so where minerals are available to act as catalysts, as would be likely in and around hydrothermal systems. Similarly, the bases (purines and pyrimidines) can be synthesized by heating solutions of ammonia and hydrogen cyanide, made elsewhere in the hydrothermal system by the reaction

$$
\mathrm{CH}_{4}+\mathrm{NH}_{3}=\mathrm{HCN}+3 \mathrm{H}_{2}
$$

with aluminum silicate catalyst. Thus, in one part of a hydrothermal system sugars could form, while elsewhere HCN could be made to be transported eventually to the site where the sugars occurred.

Hydrothermal solutions dissolve phosphorous out of lava, and in the modern earth a flux of about $5 \times 10^{11} \mathrm{~g}$ per year of $\mathrm{P}_{2} \mathrm{O}_{5}$ is released from basalt glass into the ocean (Staudigel and Hart, 1983). This may have been the main source of phosphorous to the early Archaean ocean, especially since there would have been little in the way of a sedimentary supply and possibly only small continental masses. Thus perhaps only in or near a hydrothermal system could the building bricks of polynucleotides and phosphate have been present in the Archaean Earth (Fig. 5).

\section{The Mechanism of Assembly}

In life today, the catalysts needed to assemble the complex organic polymers are enzymes. These are proteins designed and shaped to be exquisitely specific catalysts for particular reactions. It is perhaps possible that proteins were somehow inorganically assembled, and they assisted in early nucleic acid replication in the primeval stages of life (Fox and Dose, 1977).

Much more likely is the possibility that minerals provided the appropriate catalytic surfaces. This has been experimentally demonstrated by Odom and others (1979) who showed that nucleotides can bind to clays such as montmorillonite and kaolinite. Sleeper and Orgel (1979) showed that lead-containing minerals, such as galena, can also play a catalytic role in the formation of oligonucleotides. Both clays and galena are common minerals in and around hydrothermal systems.

Perhaps the most powerful catalysts, however, are zeolites. These have remarkable properties (Wright et al., 1985; Newsam, 1986) and act in ways closely comparable to the action of protein-enzymes. This is because of the zeolite cage structure (Fig. 6). The various zeolites possess a wide variety of pores of different shapes and sizes, ranging from large cages $(12 \AA)$ to one-dimensional channels of $3-7 \AA$ minimum diameter. Larger molecules are excluded or "sieved" out, while smaller molecules may enter into and pass through the huge internal volume of the zeolite.

Wright and his colleagues (1985) described the close similarity between the mode of action of enzyme catalysts and that of zeolites. In both, the shape of folds and cavities imposes a selectivity that governs the choice of reactant species, and the molecular complementarity of this microenvironment aids the chemical conversion. Wright and his colleagues have also demonstrated how an organic base (a pyridine) can be held within a zeolite framework.

Zeolites are the characteristic mineral produced by the low-grade alteration of lavas, hence the term "zeolite facies." In and around hydrothermal systems a wide variety of zeolite minerals occur, depending on local chemical and PT conditions. It is thus possible that complex organic chemicals such as oligonucleotides could have been assembled with the help of zeolite catalysts.

Thus, hydrothermal systems were probably the most favourable locations on the young Earth for the inorganic construction of polynucleotides. No other place would have had so helpful a combination of chemical species, catalysts and a flux of warm fluids of varying $\mathrm{pH}$. It is not unreasonable to suppose that somewhere in an early hydrothermal system a polynucleotide chain was once created. The probability may be low that the right

\section{A}

1)

2)

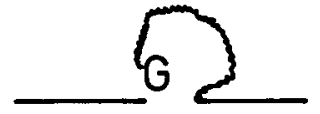

3)

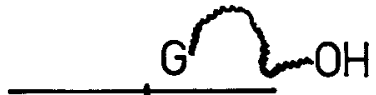

B

1)

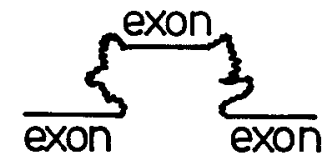

2)

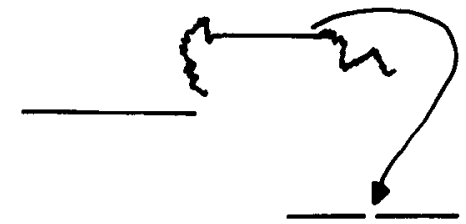

3)

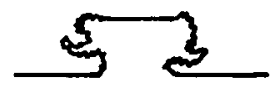

Figure 7: The strange properties of RNA (constructed after Westheimer, 1986). Numbers 3. and 5' refer to the $C$ atoms at the ends of the RNA (Fig. 1). 
polynucleotide was accidentally put together, but the steps are chemically plausible, and most have now been experimentally demonstrated in the literature cited above.

\section{The Workings of the RNA World and its Container}

Once a single ancestral RNA molecule was constructed and it would have to be the right one - how did it somehow produce, eventually, both the writer and the reader of this article? Zaug and Cech (1986) have answered a part of this problem in a paper described by Westheimer (1986) as "destined to take its place among the classics in biochemistry." Together with Guerrier-Takada and Altman (1984), Zaug and Cech have shown that in certain circumstances RNA can splice out an intervening sequence of itself, and, furthermore, that this spliced out sequence can then act as an enzyme (a ribozyme), which can in principle aid in the replication of the parent molecule.

Figure $7 \mathrm{~A}$ shows how RNA can detach an intervening sequence. Initially, the RNA consists of two information-bearing sequences called exons (shown here as straight lines) separated by the sequence to be detached (called introns). Under attack by guanosine (a nucleotide based on guanine and sugar), the intervening sequence is detached and the remaining exons are spliced together.

Figure $7 \mathrm{~B}$ shows how information can be taken from one RNA molecule to another (Gilbert, 1986). In (1) an RNA molecule contains three exons separated by intervening sequences. These intervening sequences can be detached and the remaining molecule spliced together (2). Under the right conditions the detached sequence can cleave another RNA molecule (arrow) and insert itself into it (3). The spliced out sections of RNA could take with them exons of RNA located between two introns. In this way infectious transmission of genetic material could occur from one RNA molecule to another, in a nucleic acid equivalent of sex. This would allow rapid transfer of advantageous evolutionary characteristics such as the ability, once learned, to bind amino acids and to construct proteins.

RNA is thus an extremely powerful molecule. Not only is it a "list" of instruction for a von Neumann machine, but it can also detach a part of itself as an "organ," which can, in principle, act as an enzyme to assist catalytically in RNA assembly. Furthermore, since this detached part is of the same substance as the parent, it is a daughter molecule. This is the essence of life. RNA can also transfer useful information from one individual to another. Both in its replication and in its capacity to "learn," it is subject to natural selection: it can evolve. It is thus the most likely universal ancestor.

The reactions described above take place at around $40^{\circ} \mathrm{C}$, with $\mathrm{pH}$ varying from 7.5 at certain stages to 9.0 , and with $\mathrm{Mg++}$ present. This is exactly the type of conditions that would be found near the entrances and exits of some subaerial hydrothermal systems (Fig. 5). Hydrothermal fluids in Icelandic systems are of ten of $\mathrm{pH}$ 7.5-8 (Arnórsson, 1985 ) and with temperatures varying up to boiling and down to the ambient surface temperature. In contrast, at mid-ocean ridge hydrothermal systems, the $\mathrm{pH}$ varies from 3.5 to 7 depending on temperature.

Thus, it seems that the cool meteoric water systems studied in Iceland more closely approximate the environment necessary for the RNA world than the vigorous oceanic systems. $\mathrm{Mg}^{++}$is abundant in the solutions, dissolved out of country rock. Furthermore, hydrothermal systems vary greatly, depending on fluid behaviour and the erratic behaviour of the volcanic heat source: local conditions such as $\mathrm{pH}$ and fluid composition can change rapidly. Such a setting would be ideal for the initiation of an RNA world, where reactions would be driven by changes in local $\mathrm{pH}$.
An RNA world might well exist in a test-tube, but could it have existed in nature? A suitable geological substrate clearly exists in hydrothermal systems. Cavities abound in altered lavas, ranging in size from the zeolite cages discussed above to pores and vesicles in lava up to several centimeters long. An RNA molecule, which was inorganically synthesized in such a cavity, would remain there, trapped by a molecular sieve of zeolite, while the hydrothermal fluids of varying $\mathrm{pH}$ flushed by, bearing with them smaller organic molecules, phosphate and $\mathrm{Mg}^{++}$ions able to pass through the sieve.

The significance of the container cavity is that a daughter RNA molecule or spliced-out segment would be likely to re-encounter its parent molecule. This is in contrast to what would happen in the open ocean, where a spliced-out segment would drift away to be lost and eventually destroyed: it could not act as an enzyme. An RNA world could only have existed in a very small container or series of small cavities, with passage from one to another controlled by the vagaries of hydrothermal dissolution or earthquakes.

\section{The Colonization of the RNA World}

Gilbert's RNA world must thus have existed in pore spaces in altered rock. Each pore would be lined with zeolite molecular sieves and catalysts, and there would have been limited access from pore to pore. Possibly the entire RNA world was confined to one altered pillow, or perhaps even to a few pores in a small volume of basalt. Alternatively, large volumes on the flanks of volcanoes may have been produced, up to the available supply of sugars and bases. There is, however, a time-problem here: hydrothermal systems do not usually last more than $10^{4}-10^{5}$ years in one place, so either the RNA world evolved rapidly or it was able to colonize as the hydrother mal system moved.

\section{The Development of Organs and of a Membrane}

Gilbert has outlined the next stages where an initially RNA-based replicating system developed organs of protein. A mino acids can be thermally synthesized around volcanoes from $\mathrm{CH}_{4}$ and $\mathrm{NH}_{3}$, and any hydrothermal system that produced a nucleotide would also have been able to produce these acids. Fox and Dose (1977) have reviewed the abundant experimental evidence that shows how this can be done inorganically.

In modern life, RNA molecules control the synthesis of proteins. Gilbert suggests that this was first done by developing RNA adaptor molecules that bound activated amino acids, and then by arranging them according to a template using other molecules such as the RNA core of the ribosome. Proteins are much better able to act as catalysts to aid in replication and would rapidly take over the enzyme function by natural selection, leaving modern RNA-based ribozymes as a vestigial remnant of the RNA world. These proteins would be coded by RNA exons.

The attraction of this hypothesis is that it is in accord with the central dogma of molecular biology that synthesis proceeds from information in nucleic acids to substance in proteins. At a later stage, DNA would have been invented, by reverse transcription from $\mathrm{RNA}$. With the invention of DNA a much more reliable store of information would have been developed, and double-stranded DNA would take over from RNA as the fundamental genetic library. RNA now retains its intermediate role, as the carrier of information to synthesise the proteins that form the enzymes of the organism.

We now have a mechanism for creating a self-replicating organism, but it is constrained in a rock pore in a hydrothermal system - not exactly a suitable site for colonizing the Earth. Release of this postulated initial organism would be disaster, as the components would drift away in the open ocean. How did the next stage occur? 


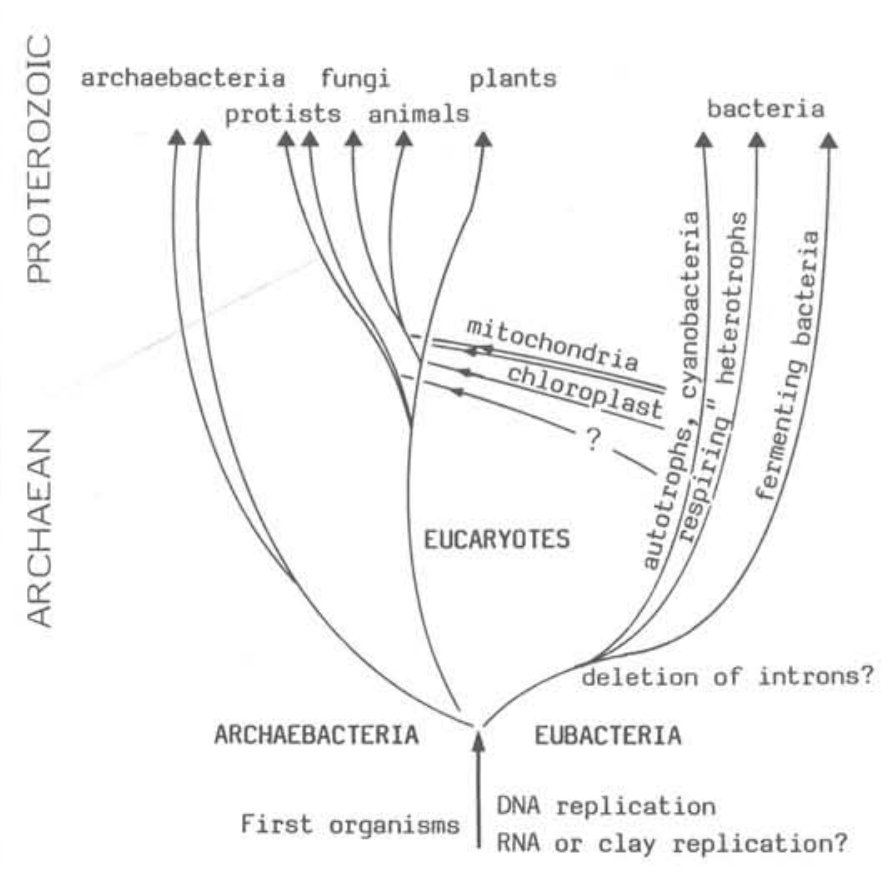

Figure 8: The descent of life (from Nisbet, in press $B$ ).

The answer seems to lie, again, with the zeolites, and with natural selection. Selection would act powerfully on the self-replicating systems, especially if they were able to exchange genetic information by swapping spliced-out segments. By this stage, once enzymes had been invented, the catalytic action of zeolites would be a capricious nuisance, interfering with the self-replication of the nucleic acids. Any strand of RNA that learned the trick of surrounding itself with a bag of phospholipids enclosing proteins would be able to isolate itself from the accidents and errors of mineral catalysis by the walls of the containing pore. Natural selection would thus very strongly favour the development of a membrane made of a lipid bilayer.

With the invention of a membrane comes the chance of managing energy supply. The first replicating molecules must have been assembled by the accidents of fluctuating $\mathrm{pH}$ and oxidation state, deriving the necessary energy from the accidents of the environment. Adenosine triphosphate (ATP) was probably of eritical importance in the initial assembly of RNA and later would have been the most suitable basic component of the first organized biosynthetic reactions. These reactions, relying on the hydrolysis of ATP, were probably at the outset random events. With the development of a cell membrane, chemiosmotic generation of ATP from adenosine diphosphate (ADP) and phosphate could have begun.

Certain other critical chemical components, such as co-enzyme A, NADH and NADPH, may also be of the greatest antiquity, if life did indeed begin with a replicating nucleic acid. It is possible that these nucleotides were present from the very beginning in a hydrothermal system, where the use of components such as co-enzyme A in the construction of a membrane would have been favoured. Most important of all is the role of phosphates, which are ubiquitous in life and which are a characteristic though minor component of hydrothermal circulation. Their presence in nucleic acids, in the critical pathways by which energy is derived in life, and in the membrane that encloses life is surely a strong clue that life began in a setting where a steady supply of phosphates was available.
Thus, by invoking mineral catalysis first, and then the extraordinary properties of RNA allied with the infectious transmission of genetic material, all under the influence of natural selection, the system changes from non-life to life (Nisbet, in press A). An assembly of components becomes an RNA world and then a living cell.

There remains the final stage. Hydrothermal systems frequently vary in activity, earthquakes occur: the replicating system surrounded by a membrane bag of lipids would spread and colonize its habitat and eventually one such proto-cell would be flushed out into the open ocean. Here it would be pre-adapted to colonize the soft sediment and altered basalt at the ocean-water interface.

\section{The Later Stages}

Figure 8 outlines the later descent from the universal ancestor. This is derived in part from the work of Woese and others (1981) on RNA sequences in a variety of modern procaryotes and eucaryotes, though there is still much controversy about the early stages. The universal ancestor appears to have produced at least three major groups of descendants. The DNA of the first group, archaebacteria, has introns, which must be spliced out through the processing of RNA before proteins can be synthesized. This characteristic appears to be primitive and to be directly derived from the RNA world.

In contrast, the second group, the eubacteria, do not have introns, and they have streamlined their genetic material. They also appear to have been the inventors of photosynthesis and the colonizers of the surface of the seas and the tidal regions. Perhaps the streamlining of the genome was an early bacterial response to the extra danger of replication error in the surface environment, where organisms living in sunlight would have been irradiated by ultraviolet light.

The third group, the eucaryotes, including ourselves, share many characteristics with archaebacteria (Woese, 1981), especially in possessing introns. However, they have also symbiotically incorporated eubacteria into their cells. By this trick some eucaryotes learned photosynthesis when they incorporated cyanobacteria into their cells, now present as the chloroplasts in plants. Other incorporations of symbiotic bacteria produced the mitochondria in each human cell.

The whole process is complex, improbable but not implausible. In Gilbert's RNA world we have, for the first time, a coherent idea of how life began. Each step has been demonstrated experimentally or is to be expected as a consequence of Darwinian selection: there are no logical leaps. It may be wildly unlikely, but it could have happened.

\section{Acknowledgements}

I thank NSERC Canada for a EWR Steacie Fellowship, which allowed this work, and E. Heppner for typing it.

Euan Nisbet is based at the Dept. of Geological Sciences, University of Saskatchewan, Saskatoon, Sask. Canada, S7N 0W0. He grew up and studied in Zimbabwe and the U.K., and has worked on the Archaean of Zimbabwe, Canada and Australia. $\mathrm{He}$ is an elder of the Presbyterian Church in Canada and holds the strong belief that the book of Genesis offers a different but equally valid perspective on the origin of life.

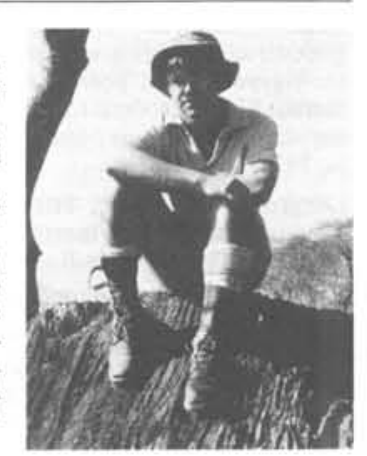




\section{References}

Abelson, P.H., 1966. Chemical events on the primitive Earth. Proceedings of the National Academy of Sciences of the U.S.A., v. 55, no. 6 , p. 1365-1 372 .

Arnórsson, S., 1985. Gas pressures in geothermal systems. Chemical Geology, v. 49 , no. 1-3, p. 319-328.

Bernal, J.D., 1951. The physical basis of life. Koutledge and Kegan Paul, London, 80p.

Bernal, J.D., 1967. The origin of life. World Publishing Co., Cleveland, New York, $345 \mathrm{p}$.

Bickle, M.J., 1978. Heat loss from the Earth: a constraint on Archaean tectonics from the relation between geothermal gradients and the rate of plate production. Earth and Planetary Science Letters, v. 40, no. 3, p. 301-315.

Buick, R., Dunlop, J.S.R., and Groves, D.I., 1981. Stromatolite recognition in ancient rocks: an appraisal of irregular laminated structures in an early Archaean chert-barite unit from North Pole, Western Australia. Alcheringa, v. 5, no. 3-4, p. 161-18l.

Byerly, G.R., Lowe, D.R. and Walsh, M.M., 1986. Stromatolite from the 3,300-3,500 Wyr Swaziland Supergroup, Barberton Mountain Land, South Africa. Nature, v. 319, no. 6053, p. 489-491.

Cairns-Smith, A.G., 1982. Genetic takeover and the mineral origins of life. Cambridge University Press, Cambridge, $477 \mathrm{p}$.

Cairns-Smith, A.G., 1985. Seven clues to the origin of life: a scientific detective story. Cambridge University Press, Cambridge, 127p. Chappell, W.R., Maglen, R.R., Runnells, D.D., Orgel, L.E., 1974. Directed panspermia. Icarus, v. 20 , no. 4, p. 513-515, 518 .

Corliss, J.B., Baross, J.A., and Hof fmann, S.E., 1981. An hypothesis concerning the relationship between submarine hot springs and the origin of life on earth. Oceanologica Acta, no. S.P., p 59-69.

Crick, F., 1981. Life itself: its origin and nature. Simon and Schuster, New York, 192p.

de Beer, Sir G. (ed.) 1959. C. Darwin. Some unpublished letters (1871). Royal Society Notes and Records, Royal Society, London, 14.1 .

Fox, S.W. and Dose, K., 1977. Molecular evolution and the origin of life. Marcel Dekker, New York, $370 \mathrm{p}$.

Froude, D.O., Ireland, T.R., Kinny, P.D., Williams, I.S., Compston, W., Williams, I.R. and J.S. Myers, 1983. Ion microprobe identification of 4,100-4,200 Myr-old terrestrial zireons. Nature, v. 304, no. 5927 , p. 616-8.

Gilbert, W., 1986. The RNA world. Nature, v. 319 , no. 6055 , p. 618 .

Guerrier-Takada, C. and Altman, S., 1984. Catalytic activity of an RNA molecule prepared by transcription in vitro. Science, v. 223 , no. 4633 , p. $285-286$.

Haldane, J.B.S., 1928. The origin of life. Rationalist Annual, p. 138153, (as reprinted in Bernal, 1967).

Henderson-Sellers, A, and Cogley, J.G., 1982. The Earth's early hydrosphere. Nature, v. 298, no. 5877, p. 832-835.

Holland, H.D., 1984. The chemical evolution of the atmosphere and oceans. Princeton University Press, Princeton, N.J., 582p.

Hoyle, F. and Wickramasinghe, N.C., 1978. Lifecloud the origin of life in the universe. Dent, London, $189 \mathrm{p}$.

Jolliffe, A.W., 1955. Geology and iron ores of Steep Rock Lake. Economic Geology, v. 50, no. 4, p. 373-398.

Kasting J.F., Pollack, J.B. and Ackerman, T.P., 1984. Response of Earth's atmosphere to increases in solar flux and implications for loss of water from Venus. Icarus, v. 57, p. 335-355.

Kristmannsdottir, H., 1983. Chemical evidence from Icelandic geothermal systems as compared to submerged geothermal systems. In: Hydrothermal processes at seafloor spreading centers, ed. P.A. Rona, K. Bostroem, L. Laubier and K.L. Smith. Nato Conference Series, IV, Marine Seiences, Plenum Press, New York, v. 12 , p. 291-320.

Langford, F.F., 1981. The Martin Group in the greater Beaverlodge area. Summary of Investigations, 1981, Saskatchewan Geological Survey, Miscellaneous Report no. 81-4, p. 38-43.

Lovelock, J.E., 1979. Gaia: a new look at life on Earth. Oxford University Press, Oxford, 157p.

Viller, S.L., 1953. A production of amino acids under possible primitive Earth conditions. Seience, v. 117 , no. 3046 , p. 528-9.
Newsam, J.M., 1986. The zeolite cage structure. Science, v. 231, no. 4742 , p. $1093-1099$.

Nisbet, E.G. and Pillinger, C.T., 1981. In the beginning. Nature, v. 289 , no. 5793 , p. 11-12.

Nisbet, E.G., 1984. The continental and oceanic erust and lithosphere in the Archaean: isostatic, thermal and tectonic models. Canadian Journal of Earth Sciences, v. 21, no. 12, p. 1426-1441.

Nisbet, E.G., in press A. RNA and hydrotherinal systems. Nature.

Nisbet, E.G., in press B. The young earth: an introduction to Archaean geology. Allen and Unwin, London.

Odom, D.G., Rao, M., Lawless, J.G. and Oro, J., 1979. Association of nucleotides with homoionic clays. Journal of Molecular Evolution, v. 12, p. 365-368.

Oparin, A.I., 1957. The Origin of Life on Earth, 3rd ed. Academic Press, New York, 495p.

Ozima, M., Podosek, F.A. and Igarashi, G., 1985. Terrestrial xenon isotope constraints on the earth history of the Earth. Nature, v. 315, no. 6019 , p. 471-4.

Richardson, S.J., Gurney, J.J., Erlank, A.J., and Harris, J.W., 1984. Origin of diamonds in an old enriched mantle. Nature, v. 310, p $198-202$.

Schidlowski, M., 1980. Antiquity of photosynthesis: possible constraints from Archaean carbon isotope record. In: Biogeochemistry of Ancient and Modern Environments, eds. P.A. Trudinger, M.R. Walter and B.J. Ralph. Springer-Verlag, Berlin, p. 47-54.

Schwartz, A.W. and Henderson-Sellers, A., 1983. Glaciers, volcanic islands and the origin of life. Precambrian Research, v. 22, no. 3-4, p. $167-174$.

Sleeper, H.L. and Orgel, L.E., 1979. The catalysis of nucleotide polymerization by compounds of divalent lead. Journal of Molecular Evolution, v. 12, p. 357-364.

Staudigel, H. and Hart, S.R., 1983. Alteration of basaltic glass: mechanisms and significance for the oceanic crust-seawater budget. Geochimica et Cosmochimica Acta, v. 47, no. 3, p. 337-350.

Stefansson, V., 1983. Physical environment of hydrothermal systems in Iceland and on submerged oceanic ridges. In: Hydrothermal processes at seafloor spreading centers, eds. P.A. Rona, K. Bostroem, L. Laubier and K.L. Smith. Nato Conference Series IV, Marine Sciences, Plenum Press, New York, v. 12, p. 321-360.

Towe, K.M., 1983. Precambrian atmospheric oxygen and banded iron formations: a delayed ocean model. Precambrian Research, v. 20, no. 2-4, p. 161-170.

van Andel, T.H., 1983. States of past oceans. Nature, v. 305 , p. 178-9.

von Neumann, J., 1966. Theory of self-reprodueing automata, ed. A.W. Burks. University of Illinois Press, Urbana, 388p.

Watson, A.J., Donahue, T.M. and Kuhn, W.R., 1984. Ternperatures in a runaway greenhouse on the evolving Venus: implications for water loss. Earth and Planetary Seience Letters, v. 68, no. 1, p. 1-6.

Westheimer, F.H., 1986. Polyribonucleic acids as enzymes. Nature, v. 319 , no. 6054 , p. $534-536$.

Woese, C.R., 1979. A proposal concerning the origin of life on the planet earth. Journal of Molecular Evolution, v. 13, p. 95-101.

Woese, C.R., 1980. An alternative to the Oparin view of the primeval sequence. In: H.O. Halvorson and K.E. van Holde, the origins of life and evolution. Alan K. Liss Inc., New York, p. 65-76.

Woese, C.R., 1981. Archaebacteria, Scientific American, v. 244 no. 6 , p. $98-122$.

Wright, P.A., Thomas, J.M., Cheetham, A.K. and Nowak, A.K., 1985. Localizing active sites in zeolite catalysis: neutron powder profile analysis and computer simulation of deuteropyridine bound to gallozeolite-L. Nature, v. 318, p. 611-614.

Zaug, A.J. and Cech, T.R., 1986. The intervening sequence RNA of "Tetrahymena" is an enzyme. Science, v. 231 , no. 4737 , p. 470-475. 